\title{
The Development of Physics Guided Inquiry Learning Package To Facilitate The Science Process Skills of Senior High School
}

\author{
Hermesianus Jehadan ${ }^{1, a^{*}}$, Mohamad Nur ${ }^{2 b}$, \& Z.A. Imam Supardi2 $2 c$ \\ ${ }^{1}$ Master Degree Program of Educational Science, State University of Surabaya, Surabaya, Indonesia \\ 2 Postgraduate State University of Surabaya, Surabaya, Indonesia \\ hermesianus.17070795007@mhs.unesa.ac.id \\ *Corresponding Author: hermesianus.17070795007@mhs.unesa.ac.id |Phone: +6281228816448
}

\begin{abstract}
The study aims to produce a guided inquiry learning materials to which is valid, practical and effective to facilitate the scientific process skills of senior high school (SMA) students on optical geometry topic. This is a development research with Four-D Model, that is Define, Design, Develop and Disseminate. This development research will be tested to the Grade XI science students of SMAN 1 Welak during their even semester of 2019/2020 using one group of pre-test and post-test. The data collection methods uses validation, observation, test and filling out questionnaries. The result of the analysis shows that: the developed learning materials is very valid; the learning process is carried out very well; and the students become more active in the learning process. The outcomes of students' science process skills are increased, showed by the $\mathrm{N}$-gain score is 0.95 which is classified in the high category. It can be said that the developed learning materials is valid, practical and effective to facilitate scientific process skills of senior high school students.
\end{abstract}

Keywords: guided inquiry model; science process skill;

\section{Introduction}

Physics is a knowledge that sistematically studies the physical properties of an object or event such as shape, weight, observation and experiment. The essence of physics as the branch of science contains four inseparable things, namely products or contents, processes, attitudes, and technologies. Chiappetta and Koballa (2010) define science as a way of thinking, a way of investigating, a body of knowledge, and science and its interaction with technology and society. Science is a way of thinking about belief, curiosity, imagination, ideas, causality, self-examination, doubt, objectivity, and open-mindedness.

Science as a way of investigating uses a variety of approaches to construct knowledge such as scientific methods, inquiry and science process skills by observations, hypotheses, experiments, etc. Science as a process is a way to obtain knowledge. Science as a body of knowledge is produced from various scientific fields which are the products of human discovery. Facts, concepts, principles, laws, theories, and models are the content of science. These products have their own meanings that cannot be understood separately from the investigation process. Science and its interaction with technology and society means that science, technology and society are influencing each other. Many scientific works carried out by the scientists are influenced by the society and the availability of technology.

The efforts of teaching students to achieve the competencies expected by the curriculum, require learning materials that help and facilitate the learning process. According to the results of observation to the physics teachers at SMAN 1 Welak during the odd semester of 2019/2020, it was found that the learning materials of process skills-based were not yet available so that the science process skills had never been trained before to the students. The results of these observations were supported by the results of the preliminary study conducted by the researcher. It is showing that the ability of students' science process skills was very low since it had never been trained before. In addition, in the previous research by Tonjo, Ramalis, and Hernani (2018) to detect the profile of science process skills of junior high school students in Lembata, NTT, showed that the ability of science process skills was in the low category.

Based on this problem, the researcher tries to develop learning materials by integrating science process skills in the learning process. Science process skill is one of the scientific skills which include formulating problems and hypotheses, identifying variables, defining variables operationally, observating, analyzing, 
and making a conclusion. It can be integrated with guided inquiry learning model as one of scientific models.

Guided inquiry model is a constructivist learning model that involves the students actively to think critically when analyzing and solving problems systematically (Suparno, 2013). One of the inquiry learning objectives is to develop the students's ability to think systematically, logically and critically, or can be said as developing their intellectual abilities as a mental process. The integrated guided inquiry model with science process skills places students in the center of activity and let them to act like a scientist in finding answers to the questions asked. Inquiry learning is a learning model which emphasizes higher-order thinking skills and processes. In this case, the higher-order thinking skills and processes are critical thinking, scientific thinking and reasoning, and metacognitive thinking (Arends, 2012). Vajoczki, Watt, Vine, \& Liao (2011) state that the inquiry learning model is a process and expertise-oriented teaching model to conduct a research.

\section{Methods}

This study is a development research of guided inquiry learning materials model to train high school student's science process skills in Physics. The development of learning materials refers to the Four -D model, namely: 1) Defining, 2) Designing, 3) Developing, 4) and Dissemination (Thiagarajan et al, 1974). The learning materials resulted includes the Lesson Plan (RPP), Student Worksheets (LKPD), textbooks on Geometry Optics, and learning outcome assessment instruments.

The study subjects used in the trial of implementing the developed learning materials are a number of 31 grade XI students of SMA Negeri 1 Welak during their even semester of 2019/2020. The trial is designed to try out the developed learning meterials, namely the physics guided inquiry learning model. The research trial design uses a one group pretest-posttest design. This design begins with giving a pretest (O1), then continues with giving treatment $(\mathrm{X})$ and in the end of the lesson, ends with giving a posttest $(\mathrm{O} 2)$ (Sugiyono, 2017).

\section{$\mathrm{O} 1 \times \mathrm{O} 2$}

The development of learning materials in this research adopted the Four -D development model. This development is more detailed and systematic to ease the researcher in the implementation.

The use of data collection techniques is to obtain relevant and accurate datas which determines the feasibility of the developed learning materials according to the research objectives. The techniques used in this research are validation, observation, tests, and questionnaires.

\subsection{Data Analysis Technique}

The technique used in analysing data collected is quantitative descriptions. The quantitative description analysis will help to classify the data according to the variable so that it is easy to interpret.

\section{Learning Materials Validity Analysis}

The materials which need to be validated includes Lesson Plan (RPP), textbooks on Geometry Optics (BAS) Student Worksheets (LKPD), and Science Process Skill Test (KPS Test). The validity analysis is conducted through calculating the average score of each component which is given by the validator based on the assessment instrument of learning materials. Then the average score obtained will be converted into the following categories:

Table 1. The criteria for assessing learning materials validity

\begin{tabular}{cc}
\hline Average Score Intervals & Categories \\
\hline $1,00 \leq \mathrm{SV} \leq 1,59$ & Invalid \\
$1,60 \leq \mathrm{SV} \leq 2,59$ & Less valid \\
$2,60 \leq \mathrm{SV} \leq 3,59$ & Valid \\
$3,60 \leq \mathrm{SV} \leq 4,00$ & Very Valid \\
\hline
\end{tabular}

Sources: (Ratumanan \& Laurens, 2015)

\section{Lesson Plan (RPP) Implementation Analysis}

To analyse the reliability of lesson plan, the research uses quantitative and qualitative descriptive analysis.The two observers who have understood the observation sheet correctly will give score to the implementation of lesson plan. Then the resulted scores will be processed and calculated using the following equation:

$$
p=\frac{\Sigma A}{\Sigma B} X 100 \%
$$

Descriptions

$\mathrm{P}$ : The percentage of lesson plan (RPP) realized, 
$\Sigma$ A: The total score of realized aspects, and

$\Sigma \mathrm{B}$ : The total number of observed aspects.

The criteria of obtained scores compares to the averages scores of the two observers is as follows :

\begin{tabular}{cc}
\hline Score Intervals & Criteria \\
\hline $1,0-1,5$ & Poor \\
$1,6-2,5$ & Fair \\
$2,6-3,5$ & Good \\
$3,6-4,0$ & Excellent \\
\hline
\end{tabular}

Sources: (Ratumanan \& Laurens, 2015).

3. Learning Outcomes Test Analysis

The analysis of learning outcomes test is obtained though pretest and posttest. The calculation of students' learning outcomes is based on the completeness of learning outcomes as cognitive products and processes. According to the regulation of Ministry of Education and Culture Number 23 of 2016, it can be obtained through the following equation:

$$
\text { Leaning Outcomes Completeness }=\frac{\text { total obtained scores }}{\text { maximum scores }} \times 100 \%
$$

The effect of guided inquiry learning models in the cognitive domain can be analyzed from the difference between the pretest and posttest. This effect can be measured using N-gain analysis which aims to determine the differences in students' knowledge of physics before and after being treated.

$$
N-\text { gain }=\frac{S_{\text {post }}-S_{\text {pre }}}{S_{\text {max }}-S_{\text {pre }}}
$$

Souces: (Hake, 1997)

Then the results of the N-gain analysis are converted with the following criteria:

Table 2. The criterias of normalize N-gain

\begin{tabular}{cc}
\hline Score Intervals & Categories \\
\hline $0,70<\mathrm{N}$-gain & High \\
$0,30 \leq \mathrm{N}$-gain $\leq 0,70$ & Average \\
$\mathrm{N}$-gain $<0,30$ & Low \\
\hline & Sources: (Hake, 1997)
\end{tabular}

\section{Research Results}

\section{a. Validity}

The developed learning materials is in the criteria of "Very Valid" and ready to be used in the learning process to train the science process skills (KPS). The validity results of developed learning materials is presented in the following chart:

Tabel 3. Validation results of learning materials development

\begin{tabular}{ll}
\hline Learning materials & Average of validation \\
\hline Syllabus & 3.92 \\
lesson plan (RPP) & 3.96 \\
Student work sheet & 3.88 \\
Affective assessment instrument & 3.67 \\
Product cognitive assessment instrument & 3.67 \\
Science process skills assessment instrument & 4.00 \\
Psychomotor assessment instrument & 3.83 \\
Textbook & 3.99 \\
\hline
\end{tabular}

\section{b. Practically}

The reliability of the Lesson Plan (RPP) 


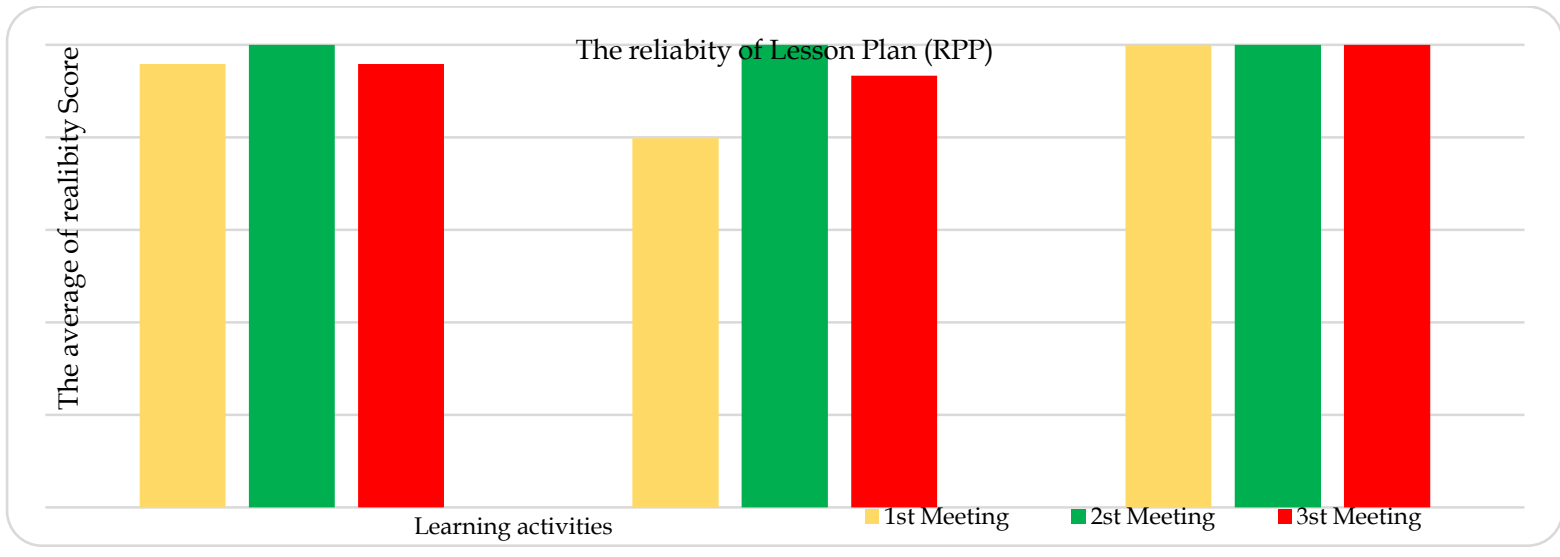

Figure 1. The reliability of the Lesson Plan (RPP)

The chart 2 shows that all the activity stages contained in the lesson plan were carried out with an average of3.97 implementation of preliminary activities with a reliability of $99.31 \%$, core activities of 3.93 with a reliability of $97.76 \%$ and a closing activity of 4.00 with a reliability of $100 \%$. Overall the implementation of Lesson Plan (RPP) is 3.94 classified as "Excellent" and its reliability is $98.18 \%$ classified as "Reliable".

\section{c. Effectiveness}

The effectiveness of the developed learning materials is obtained from the results of the science process skills test (SPS). The results of students' science process skills are carried out through the pretest and posttest. The cognitive process learning outcome test instrument uses an essay consisting of eight questions in accordance with the integrated science process skills indicator. The results of learning process skills are presented in the Table 4.

Table 4. Learning science process skills results

\begin{tabular}{|c|c|c|c|}
\hline \multirow{2}{*}{ Indicators } & \multicolumn{2}{|l|}{ Score } & \multirow{2}{*}{ N-gain } \\
\hline & Pretest & Posttest & \\
\hline Formulating the problem & 0 & 64 & \multirow{8}{*}{0.95} \\
\hline Formulating the hypothesis & 0 & 80 & \\
\hline Identifying variables & 0 & 80 & \\
\hline Defining variables operationally & 0 & 70 & \\
\hline Desigining observation table & 0 & 64 & \\
\hline Designing observation procedure & 0 & 69 & \\
\hline Analysing data & 0 & 54 & \\
\hline Make a conclusion & 0 & 64 & \\
\hline
\end{tabular}

According to the Table 4, it can be said that the science process skills of students is significantly improved after the implementation of guided inquiry learning materials model. The improvement is indicated with n-gain 0,95 which is classified as "High."

\section{Discussion}

This research is a research of learning materials development to produce a product of learning materials that meet to the criteria of validity, practicality and effectiveness (Plomp \& N. Nieveen, 2013). The developed learning materials are syllabus, lesson plan (RPP), student worksheets (LKPD), textbooks and assessment instruments. The process of developing this materials refers to the 4-D development model, starting from definition to deployment. The definition aims to define the learning requirements consisting of front-end analysis, learner analysis, task analysis, concept analysis and specifying instruction objectives to produce specific behaviors that must be achieved by students.

Based on the results of the needs analysis conducted by researchers at SMAN 1 Welak, there is no learning materials that facilitates students' science process skills (SPS). The High school students are on average over 11 years old. Based on Piaget's cognitive development stage, they who are in that ages are in the stage of formal operational. They are able to think abstractly, and purely going to the development of adult characteristics (Suparno, 2013). They are also able to solve problems through systematic experiments (Nur, Wikandari, \& Sugiarto, 2008).

The physics subject used in this research is Geometry Optics. This subject is still abstract and needs to be concrete through science process skills as outlined in the student worksheets. The curriculum competency that expected to be achieved by the students in this subject is describing how the optical instrument works 
using the properties of the reflection and refraction of light by mirrors and lenses; and analyzing the principle of reflection on the mirror and/or the refraction of light on the lens. Based on the results of the needed analysis above, the researcher designs guided inquiry-based learning materials to train science process skills in geometric optics subject. The materials developed have been through validation stages which are validated by two experts according to their fields. Each of them provides input and suggestions in order to improve learning materials both in terms of construct validity, content validity and language. The developed learning materials as shown in the Chart 1 , obtains validity average score of 3.86 which is classified as "Very Valid" and the reliability percentages of $96.99 \%$ realiable. With fulfilling category of "Very Valid" and "Reliable", the developed learning materials can be used in the learning process (Ratumanan \& Laurens, 2015). Durso and Coggins (1991) states in (Nur, Wikandari, \& Sugiarto, 2008) that well-organized learning materials will ease the learning rather than the not well organized one.

Then, the developed learning materials is tested to find out its practicality and effectiveness. The Practicality is shown by the data on the implementation of the lesson plan. There are two observers at three meetings as shown in Chart 2. The results of the observations of two observers on the implementation of learning, obtains the average scores of 3.97 which is classified as "Excellent", and the reliability percentages of $98.92 \%$ in the preliminary activities. The core activities consist of guided inquiry phases which include investigating a phenomenon, formulating questions, planning investigations, carrying out investigations, analyzing and proving, building new knowledge and making conclusions. These activities obtain average implementation scores of 3.92 which is classifies as "Excellent", and the reliability percentages of $94.18 \%$. Then, the average implementation of the closing activities is 4.00 which is classified as "Excellent", and the reliability percentages is $100.00 \%$.

Overall, the average implementation of the learning process is 3.96 which is classified as "Excellent" and the reliability is $99.30 \%$. The results of this learning implementation are supported by: $27.07 \%$ are students' activities in the preliminary study, $25.48 \%$ are students' active involvement in problem-solving activities as provided in LKPD to train science process skills in learning; $25.73 \%$ are communicating the results of observations; $21,72 \%$ are asking questions when having difficulty in learning.

The active involvement of students in learning is in accordance with Bruner's cognitive development theory which states that students learn when they are actively involved in interacting with the environment and their peers. In inquiry, the role of the teacher is to encourage active interaction and provide opportunities for students to explore their own thought processes so that the knowledge gained becomes their own (Arends, 2012). The effectiveness of the learning materials can be seen from the science process skills learning outcomes of grade XI students in SMA Negeri 1 Welak. Based on the analysis results of science process skills (SPS) pretest and posttest, it is found that the science process skills of students are significantly improved. It is indicated by the average n-gain of 0.95 . The results of the students' pretest which were carried out before the implementation of guided inquiry learning model, and aimed to determine students' initial knowledge of science process skills, obtain the average score of zero (0). This pretest resulted low since the science process skills had never been trained before.

Besides, the results of the students preliminary activities and the results of discussions with physics teachers at SMA Negeri I Welak before the research conducted, are also supported the cause of low pretest results. The given response of students to the component of science process skill is $100 \%$ said that it is new to them. Cronback \& Snow, 1997; Klahr \& Nigam, 2004; Mayer, 2004 in (Arends, 2012) believes that students should not be allowed to find concepts and processes by themselves, especially in learning new concepts and processes. Thus, the sufficient guidance is needed to develop students' abilities so that the knowledge they learned became meaningful. After the implementation of guided inquiry learning model, the learning outcomes of students' science process skills are improved in the average score of 94.67 . The improvement in learning outcomes of science process skills is supported by the positive responses from students: $88.54 \%$ states that they are interested in guided inquiry learning materials model; $88.54 \%$ states that they are easy to understand learning components such as learning materials, student worksheet, textbooks, and the way of the teacher in presenting learning materials; $87.50 \%$ states that the guided inquiry phases ease them to well understand science process skills. The positive response of students are also proven by their active involvement during solving problems on their student worksheets (LKPD).

\section{Conclusion}

According to the results of the analysis, discussion, and overall research, the developed physics guided inquiry learning materials model is classified as Very Valid, Practical and Effective to train the science process skills of high school students. 


\section{References}

Arends, R. I. (2012). Learning To Teach. Boston: McGraw-Hill.

Hake, R. R. (1997). Interactive-Engagement Versus Traditional Methods: A Six-Thousand-Student Survey Of Mechanics Test Data For Introductory Physics Courses. . Bloomington, Indiana 47405: Department of Physics, Indiana University.

Nur, M., Wikandari, P., \& Sugiarto, B. (2008). Teori-Teori Kognitif Cetakan 3. Surabaya: Pusat Sains dan Matematika Sekolah Universitas Negeri Surabaya.

Plomp, T., \& N.Nieveen. (2013). Educational Design Research - SLO. Nerherland: Enschede.

Ratumanan, T. G., \& Laurens, T. (2015). Penilaian Hasil Belajar Pada Tingkat Satuan pendidikan Edisi 3. Yogyakarta: Pensil Komunika.

ŞEN, C., \& VEKLİ, G. S. (2016). The Impact of Inquiry Based Instruction on Science Process Skills and Selfefficacy Perceptions of Pre-service Science Teachers at a University Level Biology Laboratory. Universal Journal of Educational Research 4(3).

Sugiyono. (2017). Metode Penelitian Pendidikan: Pendekatan Kuantitatif, Kualitatif, dan RED. Bandung: Alfabeta.

Suparno. (2013). Metodologi Pembelajaran Fisika Konstruktivistik dan menyenangkan Edisi Revisi. Yogjakarta: Universitas Sanata Dharma.

Thiagarajan, Semmel, D. S., \& Semmel, M. I. (1974). Instructional Development For Training of Expectional Children a Sourcebook. Bloomington: Center for Innovation on the teaching the handicaped.

Tonjo, V. A., Ramalis, T. R., \& Hernani, H. (2018). (2018). The Profile Of Science Process Skills Of Junior High School Students In Lembata. International Conference on Mathematics and Science Education of Universitas Pendidikan Indonesia.

Vajoczki, S., Watt, S., Vine, M. M., \& Liao, R. (2011). Inquiry Learning: Level, Discipline, Class Size, What Matters? International Journal for the Scholarship of Teaching and Learning: Vol. 5: No. 1, Article 10. 